\title{
Maps showing distribution of dissolved solids and dominant chemical type in ground water, Basin and Range province, Texas
}

by

Thomas H. Thompson and J. A. Nuter

\section{Introduction}

This map report is one of a series of geologic and hydrologic maps of States in the Basin and Range Province. These map reports contain information on ground-water hydrology, ground-water quality, surface distribution of selected rock types, data on tectonic conditions, areal geophysical data, Pleistocene lakes and marshes and natural resources. This information is the basis for a summary report that characterizes the Basin and Range Province. The geologic and hydrologic characterization will be used to evaluate the Province for prospective regions for further study relative to isolation of high-level radioactive waste. (Bedinger, Sargent and Reed, 1984). 
Chemical quality of ground water

Ground-water quality in the Basin and Range Province of Texas was characterized by dissolved-solids concentration and dominant anions and cations in solution. Water-quality information was compiled from the U.S. Geological survey water-quality files (WATSTORE), published reports of the U.S. Geological Survey, and the Texas Department of Water Resources.

The data on dissolved-solids concentration and water-quality type were plotted and their distributions mapped in the basin-fill deposits from the data compiled for samples collected from nongeothermal springs and wells of less than 501 feet in depth. In areas for which data were not compiled, other data sources and published reports were consulted where available. In lieu of data, the parameters in the basin-fill were estimated from the position in the ground-water flow system and the lithology of the adjacent bedrock. Data from wells greater than 500 feet in depth are included as supplemental data, but are not used in mapping dissolved-solids concentration or water-quality type. Data from wells greater than 500 feet in depth are not reflected in the mapped areas where the data are not believed to be representative of a significantly large area. 
Distribution of dissolved solids

Dissolved-solids concentration of major anions and cations was calculated from analyses using the following equation: Dissolved solids $=$

$$
\mathrm{Ca}+\mathrm{Ma}+\mathrm{Na}+(0.4917)(\mathrm{HCO})+\mathrm{SO}+\mathrm{Cl}+\mathrm{K}+\mathrm{Sr} \text {, }
$$

where the concentration of each component, calcium, $\mathrm{Ca}$; magnesium, Mg; sodium, Na; bicarbonate, HCO; sulfate, SO; chloride, $\mathrm{Cl}$; potassium, $\mathrm{K}$; and strontium, $\mathrm{Sr}$; is in milligrams per liter $(\mathrm{mg} / \mathrm{L})$.

Water-quality type

The dissolved-solids composition of a water consists primarily of six major ions: the three cations - calcium, magnesium, and sodium; and the three anions - bicarbonate, sulfate, and chloride. Relative proportions of these cations and anions can be displayed on trilinear diagrams: Waters of similar ionic proportions, and thus of similar chemical character, plot near one another. Therefore, areas of chemically similar waters can be delineated on the trilinear diagrams. For the purposes of this study, each trilinear diagram is divided into seven areas as shown in the accompanying illustration.

Water quality in basin fill is characterized by dominant cations and anions in solution and is shown in the accompanying map. The explanation lists dominant cation(s) and anion(s) combinations mapped in each area. 


\section{References cited}

Alvarez, H. J., and Buckner, A. W., 1980, Ground-water development in the El Paso region, Texas, with emphasis on the resources of the lower El Paso Valley: Texas Department of Water Resources Report 246, 346 p.

Bedinger, M. S., Sargent, K. A., and Reed, J. E., 1984, Geologic and hydrologic characterization and evaluation of the Basin and Range Province relative to the disposal of high-level radioactive waste--Part $I$, Introduction and guidelines: U.S. Geological Survey Circular 904-A, [in press].

Gates, J. S., and Stanley, W. D., 1976, Hydrologic interpretation of geophysical data from the southeastern Hueco Bolson, El Paso and Hudspeth Counties, Texas: U.S. Geological Survey Open-File Report 76-650, 37 p.

Gates, J. S., White, D. E., Stanley, W. D., and Ackerman, H. D., 1980, Availability of fresh and slightly saline ground water in the basins of westernmost Texas: Texas Department of Water Resources Report 256, 108 p.

Groat, C. G., 1972, Presidio Bolson, Trans-Pecos Texas and adjacent Mexico--Geology of a desert basin aguifer system: Austin, Texas, University of Texas Bureau of Economic Geology Report of Investigations no. $76,46 \mathrm{p}$. Hoffer, J. M., 1979, Geothermal exploration of western TransPecos Texas: El Paso, Texas, University of Texas, Science Series no. 6,78 p. 
Leggat, E. R., and Davis, M. E., 1966, Analog model study of the Hueco Bolson near El Paso, Texas: Texas Department of Water Resources Report 28, 26 p.

White, D. E., Gates, J. S., Smith, J. T., and Fry, B. J., 1978, Ground water data for the Salt Basin, Eagle Flat, Red Light Draw, Green River Valley, and Presidio Bolson in westernmost Texas: U.S. Geological Survey Open-File Report 77-575, 124 p. 